International Business Management 13 (6): 200-207, 2019

ISSN: $1993-5250$

(C) Medwell Journals, 2019

\title{
Work-Life Balance among Female Industrial Workers in Anambra State, Nigeria
}

\author{
${ }^{1}$ Ngozi Mary Eze, ${ }^{1}$ Francisca N. Onyeka, ${ }^{2}$ Ngozi Hope Chinweuba and \\ ${ }^{3}$ Chinyere Augusta Nwajiuba \\ ${ }^{1}$ Department of Home Economics and Hospitality Management Education, \\ ${ }^{2}$ Department of Educational Foundations, University of Nigeria, Nsukka, \\ PMB 410001, Enugu State, Nigeria \\ ${ }^{3}$ Department of Educational Foundation, Faculty of Education, \\ Alex Ekwueme Federal University, Ndufu-Alike, \\ PMB 1010 Abakaliki, Ebonyi State, Nigeria
}

\begin{abstract}
In recent times, both men and women regularly share the responsibility of earning for the betterment of their family. The dual roles played by the women themselves appear to have profound implications for family health and nutrition education, especially, in developing countries such as Nigeria. The aim of this study was therefore, to determine the work-life balance among female industrial workers in Anambra State, Nigeria. The study adopted a descriptive survey research design. The sample for this study was 474 female industry workers. The instrument for data collection was a questionnaire. Mean and t-test statistic was used for data analysis. The finding of the study showed among others that female workers in the industry come home late from work to prepare their family meal and long working hours have a great influence on the family meal in families. The finding of the study also showed that industrial female workers maintain an unhealthy social life, pay less attention to their spouses and children due to work and family imbalance and spend less time with their families. Finally, the study found out several feasible coping strategies being adopted by the respondents for work-life balance. Families and working-class married women should attend family health seminars, workshops and conferences to gain adequate knowledge on how to integrate work and family life as part of everyday reality. Also, industrial policy-makers should make flexible policies that will avail female workers opportunities to attend to non-work demands with minimal interference in work roles.
\end{abstract}

Key words: Work-life balance, family meal, female industrial workers, Nigeria, Anambra State, interference

\section{INTRODUCTION}

Work is a means of livelihood and for the attainment of personal and family goals (Ezeji, 2001; Okoro, 1993) working-class married women are constantly challenged by the necessity of full-time work and their responsibilities and tasks in their various homes. Many working-class women are faced with dual roles which can cause work-life conflict and a large number of these women work $40-45 \mathrm{~h} / \mathrm{week}$ and $53 \%$ of them strive to achieve work-life balance in their dual roles (Madipelli et al., 2013). There, however, seems to be a link between work-life balance and job/life satisfaction, reduced absenteeism and increased productivity (Onyeka, 2016). Achieving work-life balance can ultimately create a more satisfying workforce that contributes to productivity in the workplace (Medipelliet al., 2013). The balance between work and family roles can influence women working outside the home to make a career decision, work extra hours, make sacrifices in their personal lives and make the most of every viable opportunity (Onyeka, 2016). In Nigeria, many working- class women opt for housemaids as only a few are assisted by their husbands. Home support can reduce the amount of family conflict that female workers experience. Most women work tirelessly in their homes to meet with the demand of their household chores (Onyeka, 2016; Cole, 2004) as they perform their duties as mothers by cooking, cleaning the house, washing their children's clothes go to market to buy foodstuff, take care of both the children and their spouses. The women may be well-suited to balance work and home life if support were provided at home. Some women could afford to buy labour-saving devices like a washing machine to wash the dirty clothes in the home and some others may go for already cooked food at restaurants or to a roadside food vendor to purchase the family meals, depending on their socio-economic status. All these have implications for the family's health as well as the occupational health of the working-class women and their husbands.

Work-life imbalance can result in a work-life conflict which people run into as they strive to find leverage and/or sense of balance within and outside the work

\footnotetext{
Corresponding Author: Ngozi Hope Chinweuba, Department of Educational Foundations, University of Nigeria, Nsukka, PMB 410001, Enugu State, Nigeria
} 
environment (Onyeka, 2016). However, the work-life balance could be achieved when an individual can handle and/or manage both family responsibilities and workplace duties effectively and efficiently. A balanced work-life involves flexible working arrangements that allow parents to avail themselves of opportunities of workplace planning that provide a balance between their work and personal/family responsibilities (Uddin et al., 2013). The researchers feel that inflexible work schedules may have profound effects on family life, children's education and family health and nutrition.

In many parts of Anambra State of Nigeria, parents who choose to work long hours may encounter some negative consequences such as less caring to spouse and children, non-participation in both community and church activities which long hours of work may bring (Onyeka, 2016). Most times the children do not eat at the right time due to the absence of the mother in the home. At times, they eat poor quality food prepared by the maids and/or nannies in the house and this equally affects family meals and consequently, the health of members of the family. Imbalance in both work and family responsibilities due to long work hours and irregular schedules means more time away from the family, less time for household food, difficulty in maintaining a regular diet pattern and less opportunity to participate in the family meal. These conditions as well as the lack of access to healthy meals, force many parents to use such coping strategies as eating out meals and skipping meals (Devine et al., 2009). Pressures on women food choices have a great impact on their family meals and the health of individual members of their families (Behnke and MacDermid, 2004).

Most working-class women spend more time outside the home. Often, they are not likely to be present when their children return from school. They are not always there, especially, to assist them in some activities such as their homework and to also be present at parent-teacher meetings. The wellbeing of an individual in a family is a collective function of every other member of that particular family. When one family member struggles all others are affected (Behnke and MacDermid, 2004). As such the impact of a variable like work-hour balance affects both the parents and children, directly and/or indirectly.

The outcome of balancing work and family roles might not always be negative there might be a positive gain. When there is good family well-being, the female worker could conveniently carry out her housekeeping responsibilities such as the sweeping and cleaning of the house, cleanliness of the surroundings and washing of curtains and beddings among others (Anyakoha and Eluwa, 2008). The objective of this study was to investigate the influence of work-life balance on female industry workers in Onitsha, Anambra State, Nigeria. To guide the study, the following hypothesis were formulated and tested at 0.05 level of significance: there is no significant difference in the mean response of female workers in government-owned industries and privately owned industries on the influence of long working hours on work-life balance there is no significant difference in the mean response of female workers in the urban and rural areas on the influence of work-life balance on family wellbeing and there is no significant difference in the mean response of female industrial workers in the urban and rural areas on their work-life balance with regard to their housekeeping activities.

\section{MATERIALS AND METHODS}

The study adopted a descriptive survey research design. The participants for this study were 474 female industry workers. The sample size was determined using Yamane formula for a finite population (Uzoagulu, 2011). The statistical power of 0.70 was used to determine this sample size using GPower Software (Faul et al., 2007). Stratified random sampling technique was used to group the respondents into married and single, urban and rural, senior and junior workers, government and privately owned industry working-class women in Anambra State. Furthermore, purposive sampling technique was employed to select small and medium scale industries with an adequate number of female workers in the two local government areas that make up Onitsha (Onitsha South and Onitsha North). The Work-Life Balance Questionnaire (WBQ), a structured and validated questionnaire was used for the collection of data on the work-life balance among female industry workers. The WBQ is divided into five parts A-E. In this study, part A elicited information on personal data of the respondents such as marital status, age, workplace and the number of work hours. Part B covers the work experience of the respondents as it influences family meal $(\alpha=0.76)$. Part $\mathrm{C}$ dealt with the life experience of the workers with respect to their wellbeing $(\alpha=0.82)$. Part $\mathrm{D}$ dealt with the worker's experience as it influences their housekeeping services $(\alpha=0.73)$. Part $\mathrm{E}$ dealt with coping strategies employed by the workers $(\alpha=0.75)$. The WBQ is made up of 35 items validated by two experts in industrial and occupational health and two other experts in educational measurement and evaluation. The questionnaire has a four-point rating scale with a scoring range of point for point one strongly agree, point 2 agree, point 3 strongly disagree and point 4 disagree. The overall reliability of the WBQ was $0.93 \alpha$. Data for the study was collected with the aid of WBQ. The WBQ was administered to the study participants with the aid of three research assistants. 
All copies of the questionnaire were distributed to and retrieved completely on-the-spot from the respondents. The data collected from the respondents were analyzed using mean and t-tests. The mean was used to answer the research questions while the t-test statistic was used to test the hypothesis at 0.05 level of significance. The mean cut off mark for accepting or rejecting an item is 2.50. Any item with a mean score that is equal to 2.50 or above was regarded as accepted while any item with a mean score of $<2.50$ was regarded as not accepted. The computed significance was used in accepting or rejecting the null hypothesis. The null hypothesis was accepted, if the computed significance was greater than the alpha significance level of 0.05 at which it was tested while it was rejected, if it was less than the alpha significance level of 0.05 .

\section{RESULTS AND DISCUSSION}

Research question 1: What is the influence of the female worker's long working hours on the family meal? The result in Table 1 shows the mean and standard deviation of respondents on the influence of women's long working hours on the family meal in Onitsha, Anambra State. The results showed that item 2 and 3 had mean ratings of 3.73 and 3.55 with standard deviations of 0.51 and 0.58 , respectively. These mean values are within the real limit number of 3.50-4.00. This implies that the respondents strongly agreed with the items on the influence of long working hours on the family meal. On the other hand, items $1,4-7$ recorded mean ratings of $3.16,3.00,3.23$, 3.10 and 2.57 with standard deviations of $0.39,0.71,0.58$, 0.62 and 0.72 , respectively. These values are within the real limit of 2.50-3.49 for "Agreed". This indicates that the respondents agreed with the items on the influence of long working hours on the family meal. The cluster means of 3.19 with a standard deviation of 0.23 shows that long working hours influence family meal.

Research question 2: What is the influence of work-life balance on family wellbeing? The result in Table 2 shows the mean responses of respondents on the influence of work-life balance on family wellbeing in Onitsha, Anambra State. The results showed that item 1,3,4 and 5-9 had mean ratings of $3.41,3.13,3.40,2.76,2.75,2.85$ and 3.18 with standard deviations of $0.77,0.55,0.85$, $0.49,0.78,0.91$ and 0.51 , respectively. These mean values are within the real limit number of 2.50-3.49. This implies that the respondents agreed with the items on the influence of work-life balance on family wellbeing in Onitsha, Anambra State. However, the result also showed that item 2 and 5 recorded mean ratings of 2.02 and 1.92 with standard deviations of 0.68 and 0.80 , respectively. These values are within the real limit of $1.50-2.49$ for

Table 1: Mean ratings of respondents on the influence of female worker's long working hours on the family meal $(n=474)$ Influence of long working hours on family meal

Female workers in the industry come home late from work to prepare their family meal

Female workers in the industry usually come home tired and exhausted to prepare the family meal

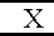

3.16

3.73

3.55

3.00

their meal demands

Female workers in the industry usually cook their dinner late when children must have gone to bed without taking their dinner most times

Female workers in the industry have the risk factor of obesity due to poor nutrition

Female workers in the industry depend on food prepared outside the home during lunch break

Female workers in the industry usually do not have time to shop for food stuff

Cluster mean

\begin{tabular}{ll} 
SD & Decision \\
\hline 0.39 & Agreed \\
0.51 & Strongly agreed \\
0.58 & Strongly agreed \\
& \\
0.71 & Agreed \\
& \\
0.58 & Agreed \\
0.62 & Agreed \\
0.72 & Agreed \\
0.23 & Agreed \\
\hline
\end{tabular}

Table 2: Mean ratings of respondents on the influence of work-life balance on family well being $(n=474)$ Work-life balance as it affects family wellbeing

Female workers in the industry see to the wellbeing of family members in terms of child caring and giving attention to the spouse

Female workers in the industry take adequate care of their family needs

Female workers in the industry maintain an unhealthy social life

Female workers in the industry have a poor concentration of their spouse and children due to work and family imbalance

Female workers in the industry do not have much time to assume their family roles

Female workers in the industry spend less time with their families

Female workers in the industry do not always have the time to take care of their children when they are sick

Female workers in the industry do not attend adequately to their children's education activities at home such as of assignment/homework

Female workers in the industry do not devote time to see that their children take a siesta in the afternoon after school work

Cluster mean

$\mathrm{X}$ : Mean, SD: Standard deviation

\begin{tabular}{|c|c|c|}
\hline $\mathrm{X}$ & SD & Decision \\
\hline 3.41 & 0.77 & Agreed \\
\hline 2.02 & 0.68 & Disagreed \\
\hline 3.13 & 0.55 & Agreed \\
\hline 3.40 & 0.85 & Agreed \\
\hline 1.92 & 0.80 & Disagreed \\
\hline 2.76 & 0.49 & Agreed \\
\hline 2.75 & 0.78 & Agreed \\
\hline 2.85 & 0.91 & Agreed \\
\hline 3.18 & 0.51 & Agreed \\
\hline 2.71 & 0.23 & Agreed \\
\hline
\end{tabular}


Int. Business Manage., 13 (6): 200-207, 2019

Table 3: Mean ratings of respondents on the influence of female industrial workers and housekeeping services $(n=474)$

\begin{tabular}{llll}
\hline Influence of female industrial workers and housekeeping services & $\mathrm{X}$ & SD & Decision \\
\hline Female industry workers usually take care of production activities in the industry & 3.20 & 0.53 & Agreed \\
Female industry workers see to housekeeping chores in their homes & 3.47 & 0.52 & Agreed \\
Female industry workers do see to the cleanliness of their environments both at work and at home & 3.05 & 0.44 & Agreed \\
Female industry workers launder/wash their children's clothing spouse and household linen-like curtains & 3.58 & 0.53 & Strongly agreed \\
Female industry workers purchase some household equipment in the form of labour saving devices for & 2.84 & 0.55 & Agreed \\
efficient work in the home to save time and energy & & & \\
Female industry workers prepare children and take them to school and equally go to their own workplace & 3.14 & 0.59 & Agreed \\
Female industry workers see to the mending of torn materials and replacement of new ones & 2.77 & 0.68 & Agreed \\
Female industry workers carry out housekeeping chores alongside their busy work schedules & 3.32 & 0.88 & Agreed \\
Cluster mean & 3.17 & 0.23 & Agreed \\
\hline
\end{tabular}

Cluster mean

$\mathrm{X}$ : Mean, SD: Standard deviation

Table 4: Mean ratings of respondents on the coping strategies the women adopted to balance work in the industry and family life $(n=474)$.

\begin{tabular}{|c|c|c|c|}
\hline Coping strategies employed by the female workers $\mathrm{ft}$ & $\mathrm{X}$ & $\mathrm{SD}$ & Remarks \\
\hline Female industry workers employ the service of nannies/maids to assist them in their homes & 3.41 & 0.84 & Agreed \\
\hline Female industry workers at times seek help from relations for them to cope with both work role and family role & 3.10 & 0.83 & Agreed \\
\hline Female industry workers plan ahead of time to avoid role conflict & 2.92 & 0.78 & Agreed \\
\hline Female industry workers purchase food ingredient and cook ahead of time and preserve for future use & 2.20 & 0.57 & Disagreed \\
\hline Female industry workers, under busy schedule, buy already prepared food outside the home & 2.63 & 0.60 & Agreed \\
\hline $\begin{array}{l}\text { Female industry workers require both the support and cooperation of the spouse and that of } \\
\text { the employer to maintain work-life balance }\end{array}$ & 2.92 & 0.54 & Agreed \\
\hline Female industry workers need flexible working hours to ease off her workload and reduce stress & 2.88 & 0.55 & Agreed \\
\hline $\begin{array}{l}\text { Female industry workers need to be adequately motivated in order to manage the demands of } \\
\text { work and personal life }\end{array}$ & 2.74 & 0.55 & Agreed \\
\hline Female industry workers employ work simplification skill in their various homes & 2.85 & 0.68 & Agreed \\
\hline Female industry workers engage in bulk-buying to save time and energy & 2.48 & 0.77 & Disagreed \\
\hline $\begin{array}{l}\text { Female industry workers make use of labour- saving devices as part of their strategies to balance } \\
\text { work life and family life }\end{array}$ & 2.95 & 0.56 & Agreed \\
\hline Cluster men & 2.73 & 0.25 & Agreed \\
\hline
\end{tabular}

$\mathrm{X}$ : Mean, SD: Standard deviation, Remark: Decision

"Disagreed". This indicates that the respondents disagreed with the items on the influence of work-life balance on family wellbeing in Onitsha, Anambra State. The cluster means of 2.71 with a standard deviation of 0.23 shows that work-life balance influences family wellbeing.

Research question 3: To what extent does work-life balance influence female industrial workers and housekeeping services? The results in Table 3 show the mean ratings of respondents on the influence of work-life on female industrial workers and housekeeping services in Onitsha, Anambra State. The results showed that item 4 had a mean rating of 3.58 with a standard deviation of 0.53 indicating that respondents strongly agreed with the item on the influence of work-life on female industrial workers and housekeeping services. On the other hand, item 1, 2, 3 and 5-8 recorded mean scores of $3.20,3.47$, $3.05,2.84,3.14,2.77$ and 3.32 with standard deviations of $0.53,0.52,0.44,0.55,0.59,0.68$ and 0.88 , respectively. These values are within the real limit of 2.50-3.49 for "Agreed". This indicates that the respondents agreed with the items on the influence of work-life on female industrial workers and housekeeping services. The cluster means of 3.17 with a standard deviation of 0.23 shows respondents opinions were not far from each other. The work-life of female industrial workers exert influence on their housekeeping services in Onitsha, Anambra State.
Research question 4: What are the coping strategies the women adopted to balance work in the industry and family life? The result in Table 4 presents the mean and standard deviation of respondents on the coping strategies women employed to balance work in the industry and family life in Onitsha, Anambra State. Result showed that item 1-3, 5-9 and 11 had mean ratings of $3.41,3.10,2.92$, $2.63,2.92,2.88,2.74,2.85$ and 2.95 with standard deviation of $0.84,0.83,0.78,0.60,0.54,0.55,0.55,0.68$ and 0.56 , respectively. These mean values are within the real limit number of 2.50-3.49. This implies that the respondents agreed with the items on the coping strategies women employed to balance work in the industry and family life in Onitsha, Anambra State. However, the result also showed that item 10 recorded mean ratings of 2.48 with standard deviations of 0.77 . This value is within the real limit of 1.50-2.49 for "Disagreed". This indicates that the respondents disagreed with the item on the coping strategies women employed to balance work in the industry and family life in Onitsha, Anambra State. The cluster means of 2.73 with a standard deviation of 0.25 shows that the respondents were not far from one another in their opinions.

Hypothesis 1: There is no significant difference in the mean response of female workers in government-owned industries and privately owned industries on the influence of long working hours. 
Int. Business Manage., 13 (6): 200-207, 2019

Table 5: t-test analysis of the mean response of female workers in government-owned industries and privately owned industries on the influence of long working hours on work-life balance

\begin{tabular}{|c|c|c|c|c|c|c|c|}
\hline \multirow[b]{2}{*}{ Influence of long working hours } & \multicolumn{7}{|c|}{ Government Owned $(\mathrm{GO}), \mathrm{n}=214$, Privately Owned $(\mathrm{PO}), \mathrm{n}=260$} \\
\hline & Status & $\mathrm{X}$ & $\mathrm{SD}$ & t-values & df & Sig. & Dec \\
\hline \multirow{2}{*}{$\begin{array}{l}\text { Female workers in the industry come home late from work to } \\
\text { prepare their family meal }\end{array}$} & Government-owned & 3.15 & 3.16 & - & 472 & 0.84 & $\mathrm{NS}$ \\
\hline & Privately owned & 0.42 & 0.37 & 0.20 & & & \\
\hline \multirow{2}{*}{$\begin{array}{l}\text { Female workers in the industry usually come home tired and } \\
\text { exhausted to prepare the family meal }\end{array}$} & Government-owned & 3.71 & 3.74 & - & 472 & 0.48 & NS \\
\hline & Privately owned & 0.50 & 0.49 & 0.70 & & & \\
\hline \multirow{2}{*}{$\begin{array}{l}\text { Female workers in the industry suffer from stress after daily } \\
\text { work, therefore, they cannot meet up with their meals }\end{array}$} & Government-owned & 3.44 & 3.64 & - & 472 & 0.00 & $\mathrm{~S}$ \\
\hline & Privately owned & 0.67 & 0.48 & 0.37 & & & \\
\hline \multirow{2}{*}{$\begin{array}{l}\text { Female workers in the industry usually cook their dinner } \\
\text { late when children must have gone to bed without taking } \\
\text { their dinner most times }\end{array}$} & Government-owned & 3.07 & 0.70 & 1.97 & 472 & 0.05 & $\mathrm{~S}$ \\
\hline & Privately owned & 2.95 & 0.72 & & & & \\
\hline \multirow{2}{*}{$\begin{array}{l}\text { Female workers in the industry have the risk factor of obesity } \\
\text { due to poor nutrition }\end{array}$} & wned & 3.13 & 0.68 & - & 472 & 0.00 & $\mathrm{~S}$ \\
\hline & Privately owned & 3.32 & 0.47 & 0.37 & & & \\
\hline \multirow{2}{*}{$\begin{array}{l}\text { Female workers in the industry depend on food prepared } \\
\text { outside the home during lunch break }\end{array}$} & Government-owned & 3.08 & 0.65 & - & 472 & 0.59 & NS \\
\hline & Privately owned & 3.12 & 0.60 & 0.54 & & & \\
\hline \multirow{4}{*}{$\begin{array}{l}\text { Female workers in the industry usually do not have time } \\
\text { always to go for foodstuff shopping } \\
\text { Cluster t }\end{array}$} & Government-owned & 2.59 & 0.74 & 0.70 & 472 & 0.03 & $\mathrm{~S}$ \\
\hline & Privately owned & 2.56 & 0.47 & & & & \\
\hline & Government-owned & 3.16 & 0.24 & - & 472 & 0.04 & $\mathrm{~S}$ \\
\hline & Privately owned & 3.21 & 0.22 & 2.06 & & & \\
\hline
\end{tabular}

NS: Not significant, S: Significant

Result in Table 5 shows the t-test analysis of the significant difference in the mean response of female workers in government-owned industries and privately owned industries on the influence of long working hours on work-life balance. The result shows that on items 1,2 and 6 there was no significant difference between government-owned industries and privately owned industries on the influence of long working hours on work-life balance. However, items 3, 4, 5 and 7 show significant differences in the mean responses of female workers in government-owned industries and privately owned industries on the influence of long working hours on work-life balance. This is because all the probability values are $<0.05$ set as the level of significance. The cluster t-value of -2.06 with a degree of freedom of 472 and a probability value of 0.04 was obtained. Since, the probability value of 0.04 is $<0.05$, this means that the hypothesis which stated that there is no significant difference in the mean response of female workers in government-owned industries and privately owned industry on the influence of long working hours on work-life balance is rejected. The inference drawn, therefore is that the female workers in government-owned industries and privately owned industries differ significantly in their responses on the influence of long working hours on work-life balance in Onitsha Anambra State.

Hypothesis 2: There is no significant difference in the mean response of female workers in the urban and rural areas on the influence of work-life balance on family wellbeing.

Result in Table 6 shows the t-test analysis of the significant difference in the mean response of female workers in the urban and rural areas on the influence of work-life balance on family wellbeing. Results show that in items 1 and 3 there was a significant difference between female workers in the urban and rural areas on the influence of work-life balance on family wellbeing. However, items 2, 4-9 show no significant difference in the mean responses of female workers in the urban and rural areas on the influence of work-life balance on family wellbeing. This is because all the probability values are $>0.05$ set as the level of significance for testing the hypothesis. The cluster $t$-value of 0.78 with a degree of freedom of 472 and a probability value of 0.43 was obtained. Since, the probability value of 0.43 is $>0.05$ this means that the hypothesis which stated that there is no significant difference in the mean response of female workers in the urban and rural areas on the influence of work-life balance on family wellbeing is accepted. The inference drawn, therefore is that the female workers in the urban and rural areas did not differ significantly in their responses on the influence of work-life balance on family wellbeing in Onitsha Anambra State.

Hypothesis 3: There is no significant difference in the mean response of female industrial workers in the urban area and the rural areas on the influence of work-life balance on their housekeeping activities.

Result in Table 7 shows the t-test analysis of the significant difference in the mean response of female industrial workers in the urban area and the rural areas on their work-life balance with regard to their housekeeping activities. The result on item 1 shows that there is a significant difference between female industrial workers in the urban area and the rural areas on their work-life balance with regard to their housekeeping activities. However, items 2-8 shows no significant differences in the mean responses of female industrial workers in the urban area and the rural areas on their work-life balance 
Int. Business Manage., 13 (6): 200-207, 2019

Table 6: t-test analysis of the mean response of female workers in the urban and rural areas onthe influence of work-life balance on family wellbeing

\begin{tabular}{|c|c|c|c|c|c|c|c|}
\hline \multirow[b]{2}{*}{ Items statement } & \multicolumn{7}{|c|}{ Urban, $\mathrm{n}=260$, Rural, $\mathrm{n}=214$} \\
\hline & Status & $\mathrm{X}$ & $\mathrm{SD}$ & t-values & $\mathrm{df}$ & Sig. & Dec. \\
\hline \multirow{2}{*}{$\begin{array}{l}\text { Female workers in the industry see the wellbeing of family members in } \\
\text { terms of child caring and spouse }\end{array}$} & Urban & 3.53 & 0.64 & 3.81 & 472 & 0.00 & $\bar{S}$ \\
\hline & Rural & 3.26 & 0.89 & & & & \\
\hline \multirow[t]{2}{*}{ Female workers in the industry take adequate care of their family needs } & Urban & 1.99 & 0.69 & -1.23 & 472 & 0.21 & NS \\
\hline & Rural & 2.07 & 0.66 & & & & \\
\hline \multirow[t]{2}{*}{ Female workers in the industry maintain an unhealthy social life } & Urban & 3.18 & 0.52 & 2.35 & 472 & 0.02 & $\mathrm{~S}$ \\
\hline & Rural & 3.07 & 0.59 & & & & \\
\hline \multirow{2}{*}{$\begin{array}{l}\text { Female workers in the industry have a poor concentration of their spouse } \\
\text { and children due to work and family imbalance }\end{array}$} & Urban & 2.38 & 0.85 & -0.51 & 472 & 0.61 & NS \\
\hline & Rural & 2.42 & 0.85 & & & & \\
\hline \multirow{2}{*}{$\begin{array}{l}\text { Female workers in the industry do not have much time to assume their } \\
\text { family roles }\end{array}$} & Urban & 1.88 & 0.79 & -1.18 & 472 & 0.24 & NS \\
\hline & Rural & 1.97 & 0.82 & & & & \\
\hline \multirow[t]{2}{*}{ Female workers in the industry spend less time with their families } & Urban & 2.77 & 0.48 & 0.45 & 472 & 0.65 & NS \\
\hline & Rural & 2.75 & 0.51 & & & & \\
\hline \multirow{2}{*}{$\begin{array}{l}\text { Female workers in the industry do not have the chance always to take care } \\
\text { of their children when they are sick }\end{array}$} & Urban & 2.78 & 0.76 & 0.73 & 472 & 0.47 & NS \\
\hline & Rural & 2.72 & 0.81 & & & & \\
\hline \multirow{2}{*}{$\begin{array}{l}\text { Female workers in the industry do not attend adequately to their children's } \\
\text { educational activities at home such as assignment/homework }\end{array}$} & Urban & 2.81 & 0.92 & -0.91 & 472 & 0.36 & NS \\
\hline & Rural & 2.89 & 0.89 & & & & \\
\hline \multirow{4}{*}{$\begin{array}{l}\text { Female workers in the industry do not devote time to see that their children } \\
\text { take a siesta in the afternoon after school work } \\
\text { Cluster t }\end{array}$} & Urban & 3.16 & 0.51 & -0.86 & 472 & 0.39 & NS \\
\hline & Rural & 3.20 & 0.47 & & & & \\
\hline & Urban & 2.72 & 0.23 & 0.78 & 472 & 0.43 & NS \\
\hline & Rural & 2.71 & 0.20 & & & & \\
\hline
\end{tabular}

Table 7: t-test analysis of the mean response of female workers in the urban and rural areas on the influence of work-life balance on their housekeeping activities

\begin{tabular}{|c|c|c|c|c|c|c|c|}
\hline \multirow[b]{2}{*}{ Items statement } & \multicolumn{7}{|c|}{ Urban, $n=260$, Rural, $n=214$} \\
\hline & Status & $\mathrm{X}$ & $\mathrm{SD}$ & t-values & $\mathrm{df}$ & Sig. & Dec. \\
\hline \multirow{2}{*}{$\begin{array}{l}\text { Female industry workers usually take care of production activities } \\
\text { in the industry }\end{array}$} & Urban & 3.15 & 0.54 & - & 472 & 0.04 & $\overline{\mathrm{S}}$ \\
\hline & Rural & 3.25 & 0.51 & 2.12 & & & \\
\hline \multirow[t]{2}{*}{ Female industry workers see to housekeeping chores in their homes } & Urban & 3.45 & 0.54 & - & 472 & 0.39 & NS \\
\hline & Rural & 3.50 & 0.51 & 0.86 & & & \\
\hline \multirow{2}{*}{$\begin{array}{l}\text { Female industry workers see to the cleanliness of their environment } \\
\text { both at work and home }\end{array}$} & Urban & 3.03 & 0.43 & - & 472 & 0.19 & NS \\
\hline & Rural & 3.08 & 0.45 & 1.30 & & & \\
\hline \multirow{2}{*}{$\begin{array}{l}\text { Female industry workers launder/wash their children's clothing/ } \\
\text { spouse and household linen-like curtains }\end{array}$} & Urban & 3.59 & 0.52 & 0.46 & 472 & 0.65 & NS \\
\hline & Rural & 3.57 & 0.54 & & & & \\
\hline \multirow{2}{*}{$\begin{array}{l}\text { Female industry workers purchase some household equipment in the } \\
\text { form of labour-saving devices for efficient work in the home to } \\
\text { save time and energy }\end{array}$} & Urban & 2.81 & 0.55 & - & 472 & 0.19 & NS \\
\hline & Rural & 2.88 & 0.54 & 1.32 & & & \\
\hline \multirow{2}{*}{$\begin{array}{l}\text { Female industry workers prepare children and take them to school } \\
\text { and equally go to their workplace }\end{array}$} & Urban & 3.15 & 0.61 & 0.61 & 472 & 0.54 & NS \\
\hline & Rural & 3.12 & 0.57 & & & & \\
\hline \multirow{2}{*}{$\begin{array}{l}\text { Female industry workers see to the mending of torn materials and } \\
\text { replacement of new ones }\end{array}$} & Urban & 2.80 & 0.68 & 1.13 & 472 & 0.26 & NS \\
\hline & Rural & 2.73 & 0.68 & & & & \\
\hline \multirow{4}{*}{$\begin{array}{l}\text { Female industry workers carry out housekeeping chores alongside } \\
\text { their busy work schedule } \\
\text { Cluster }\end{array}$} & Urban & 3.31 & 0.88 & - & 472 & 0.68 & NS \\
\hline & Rural & 3.34 & 0.88 & 0.41 & & & \\
\hline & Urban & 3.16 & 0.23 & - & 472 & 0.29 & NS \\
\hline & Rural & 3.18 & 0.20 & 1.07 & & & \\
\hline
\end{tabular}

NS: Not significant, S: Significant

with regard to their housekeeping activities. This is because all the probability values are $>0.05$ set as the level of significance for testing the hypothesis. The cluster t-value of -1.07 with a degree of freedom of 472 and a probability value of 0.29 was obtained. Since, the probability value of 0.29 is $>0.05$ this means that the hypothesis which stated that there is no significant difference in the mean response of female industrial workers in the urban area and the rural areas on their work-life balance with regard to their housekeeping activities is accepted. The inference drawn, therefore is that the female workers in the urban and rural areas differ significantly in their responses on the influence of work-life balance on their housekeeping activities in Onitsha Anambra State.

The main objective of the current study was to determine the work-life balance among female industrial workers in Anambra State, Nigeria. Findings on the influence of women's long working hours on the family meal in Onitsha Anambra State revealed that female workers come home late from work to prepare their family meal. They usually come home tired and exhausted to prepare the family meal, suffer from stress after daily work and therefore, they cannot meet with their meals, 
cook their dinner late when children must have gone to bed without taking their dinner most times. Findings showed that female workers in the industry have the risk factor of obesity due to poor nutrition, depend on food prepared outside the home during lunch break and do not always have time to go shop for foodstuff. The current study outcomes are in line with the assertion made by Sackey and Sanda (2009) who stated that work and home conflicts are associated with high stress in employed female in the industries and such stress takes its toll on a woman's physical and mental health. In line with this Cole (2004) stated that conflict occurs when the employees extend their efforts to satisfy their work demands at the expense of their family demands or vice versa. The conflict could arise from work interfering with the family life, such as working overtime to meet the demands of the job or from family demands such as the illness of a family member. Also, the present study showed there was a significant difference in the mean response of female workers in government-owned industries and private-owned industries in the long working hours. This supports Onyeka (2016) who found that female workers in government-owned industries and privately owned industries significantly differ on long working hours.

Findings on the influence of work-life balance on family wellbeing showed that female workers in the industry seek the wellbeing of family members they do not take adequate care of their family needs, maintain unhealthy social life have poor concentration of their spouse and children due to work and family imbalance, spend less time with their family do not have chance always to take care of their children when they are sick, do not attend adequately to their children's education activities at home such as assignment/homework and do not devote time to see that their children take siesta in the afternoon after school work. This study agreed with Kalliath and Brough (2008) who believed that work-life balance is drawn from an individual's multiple life roles derived from the early recognition that non-work (family or personal) demands may carry over into the working day and adversely influence individual health and performance at work. Work-life balance can be seen as an individual achieving satisfaction between his/her multiple roles but encountering minimum conflict. Greenhaus et al. (2003) also agreed with the study when they started work-family balance as "the extent to which an individual is equally-self engaged and equally satisfied with his or her work role and family role. Work-life balance does not mean an equal balance in units of time between work and life. Also, the current study showed that the female workers in the urban and rural area did not differ significantly in their responses on their work-life balance on family well being in Onitsha Anambra State. The finding supports those of Onyeka (2016) who found that female workers in the urban and rural areas do not differ significantly on the influence of their work-life balance on family well being.

Findings on the extent work-life balance influenced female industrial workers and housekeeping services indicated that female industry workers usually take care of production activities in the industry, female industry workers see to housekeeping chores in their homes, female industry workers equally see to the cleanliness of their environments both at work and home, female industry workers launder/wash their children clothing/spouse and household linen-like curtains, female industry workers purchase some household equipment in the form of labour-saving devices for efficient work in the home in order to save time and energy, female industry workers prepare children and take them to school and equally go to their workplace, female industry workers see to the mending of torn materials and replacement of new ones and female industry workers carry out housekeeping chores alongside their work busy schedule. This study is in agreement with McDonald and Bradley (2005) who stated that work-life balance is not more related to work and life, rather it is the positive state of mind. Work-life balance, in its broadest sense is a satisfactory level of involvement or 'fit' between the multiple roles in a person's life. Furthermore, the present study showed that there was a significant difference in the mean response of female industrial workers in the urban area and the rural areas on their work-life balance with regard to their housekeeping activities. The study finding supports those of Onyeka (2016) that significant differences exist in the mean response of female industrial workers in the urban area and the rural areas on their work-life balance with regard to their housekeeping activities

Findings on the coping strategies women employed to balance work in the industry and family life revealed that female industry workers employ the services of Nannies/maids to assist them in the home, female industry workers at times seek help from relations for them to cope with both work role and family role, female industry workers plan ahead of time to avoid role conflict, female industry workers, under busy schedule, buy already prepared food outside the home, female industry workers require both the support and cooperation of the spouse and that of the employer to maintain work-life balance. Findings also showed that female industry workers need flexible working hours to ease off their workload and reduce stress, female industry workers need to be adequately motivated to manage the demands of work and personal life and female industry workers employ work-simplification skill in their various homes. According to Folkman and Moskowitz (2005), the coping 
process is introduced in response to an individual's assessment that significant goals have been lost, endangered or harmed.

\section{CONCLUSION}

Long working hours have a great influence on the family meal. Work-life balance also influences family wellbeing. The work-life of female industrial workers as found in the study exerts influence on their housekeeping services in Onitsha, Anambra State. Industrial policy-makers should make flexible policies that will avail the female workers of the opportunity to attend to non-work demands with minimal interference in work roles. Female industrial workers should be trained by employers to manage their time requirement for household chores and paid work that often results in role conflict. The government should create a sensitization programme for the general public, especially, the female industrial workers that will expose them to some coping strategies, especially during stressful conditions. Families should attend seminars, workshops and conferences to gain adequate knowledge on how to integrate work and family life as part of everyday reality.

\section{REFERENCES}

Anyakoha, E. and M. Eluwa, 2008. Home management for schools and colleges. Africana First Publishers, Onitsha, Nigeria,

Behnke, A. and S. MacDermid, 2004. Family well-being. Work and Family Researchers Network, Ithaca, New York, USA. https://wfrn.org/encyclopedia/familywell-being/

Cole, D.W., 2004. Social reflection on women playing dual roles: An assessment of women in leadership positions. J. Gender Stud., 7: 126-132.

Devine, C.M., T.J. Farrell, C.E. Blake, M. Jastran and $\mathrm{E}$. Wethington et al., 2009. Work conditions and the food choice coping strategies of employed parents. J. Nutr. Educ. Behave., 41: 365-370.
Ezeji, S.C.O.A., 2001. Guidance and Counseling in Education. Chulbson International Press, Nsukka, Nigeria,

Faul, F., E. Erdfelder, A.G. Lang and A. Buchner, 2007. G*Power 3: A flexible statistical power analysis program for the social, behavioral and biomedical sciences. Behav. Res. Methods, 39: 175-191.

Folkman, S.K. and Moskowitz, 2005. Stress Appraisal and oping. Springer Publishing, New York, USA.,

Greenhaus, J.H., K.M. Collins and J.D. Shaw, 2003. The relation between work-family balance and quality of life. J. Vocational Behav., 63: 510-531.

Kalliath, T. and P. Brough, 2008. Work life balance: A review of the meaning of the balance construct. $\mathrm{J}$. Manage. Organiz., 14: 323-327.

Madipelli, S., V.S.V. Sarma and Y. Chinnappaiah, 2013. Factors causing work life imbalance among working women-a study on school teachers. Indian J. Ind. Relat., 48: 621-633.

McDonald, P. and L.M. Bradley, 2005. The Case for Work-Life Balance: Closing the Gap between Policy and Practice. Hudson Global Resources (Aust.) Pty Limited, Australia,.

Okoro, O.M., 1993. Principles and Methods in Vocational and Technical Education. University Trust Publishers, Nsukka, Nigeria,

Onyeka, F.N., 2016. Work-life balance among female industrial workers in Onitsha Anambra State Master's thesis, University of Nigeria, Nsukka, Nigeria.

Sackey, J. and M.A. Sanda, 2009. Influence of occupational stress on the mental health of Ghanaian professional women. Intl. J. Ind. Ergon., 39: 876-887

Uddin, M.R., A.M.A. Mamun, N. Hoque and M.S. Uddin, 2013. Work-life balance: A study on female teachers of private education institutions of Bangladesh. Intl. J. Afr. Asian Stud., 1: 101-107.

Uzoagulu, A.E., 2011. Practical Guide to Writing Research Project Reports in Tertiary Institutions. Cheston Agency Ltd, Enugu, Nigeria, 